DOE/MC/20422-94/C0315

Gas Hydrate Detection and Mapping on the U.S. East Coast

Authors:

T.S. Ahlbrandt

W.P. Dillon

Contractor:

U.S. Geological Survey

Reston, VA 22092

Contract Number:

DE-Al21-83MC20422

Conference Title:

Fuels Technology Contractors Review Meeting

Conference Location:

Morgantown, West Virginia

Conference Dates:

November 16-18, 1993

Conference Sponsor:

U.S. Department of Energy, Morgantown Energy Technology Center

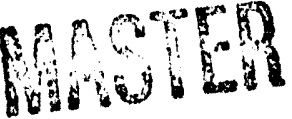




\section{DISCLAIMER}

This report was prepared as an account of work sponsored by an agency of the United States Government. Neither the United States Government nor any agency thereof, nor any of their employees, makes any warranty, express or implied, or assumes any legal liability or responsibility for the accuracy, completeness, or usefulness of any information, apparatus, product, or process disclosed, or represents that its use would not infringe privately owned rights. Reference herein to any specific commercial product, process, or service by trade name, trademark, manufacturer, or otherwise does not necessarily constitute or imply its endorsement, recommendation, or favoring by the United States Government or any agency thereof. The views and opinions of authors expressed herein do not necessarily state or reflect those of the United States Government or any agency thereof.

This report has been reproduced directly from the best available copy.

Available to DOE and DOE contractors from the Office of Scientific and Technical Information, 175 Oak Ridge Turnpike, Oak Ridge, TN 37831; prices available at $(615) 576-8401$.

Available to the public from the National Technical Information Service, U.S. Department of Commerce, 5285 Port Royal Road, Springfield, VA 22161; phone orders accepted at (703) 487-4650. 


\title{
Gas Hydrate Detection and Mapping on the U.S. East Coast
}

\author{
CONTRACT INFORMATION
}

Interagency Agreement

DE-AI21-83MC20422

Contractor

U.S. Geological Survey

Reston VA 22092

703-648-6470

Contract Project Manager

Thomas S. Ahlbrandt

Principal Investigator

William P. Dillon

METC Project Manager

Rodney D. Malone

Schedule and Milestones

FY94/95 Program Schedule

analyze Blake Ridge seismic data

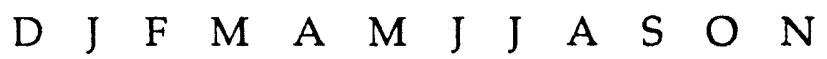
carry out lab testing of hydrates support ODP drilling proposal

\section{OBJECTIVES}

Project objectives are to identify and map gas hydrate accumulations on the U.S. eastern continental margin using remote sensing (seismic profiling) techniques and to relate these concentrations to the geological factors that control them. In order to test the remote sensing methods, gas hydrate-cemented sediments will be tested in the laboratory and an effort will be made to perform similar physical tests on natural hydrate-cemented sediments from the study area. Gas hydrate potentially may represent a future major resource of energy. Furthermore, it may influence climate change because it forms a large reservoir for methane, which is a very effective greenhouse gas; its breakdown probably is a controlling factor for sea-floor landslides; and its presence has significant effect on the acoustic velocity of sea-floor sediments. 


\section{BACKGROUND INFORMATION}

A gas hydrate is a crystalline solid; its building blocks consist of a gas molecule surrounded by a cage of water molecules. Thus it is similar to ice, except that the crystalline structure is stabilized by the guest gas molecule within the cage of water molecules. Many gases have molecular sizes suitable to form hydrate, including such naturally occurring ones as carbon dioxide, hydrogen sulfide, and several lowcarbon-number hydrocarbons, but most marine gas hydrates that have been analyzed are methane hydrates. Gas hydrates are stable at the temperatures and pressures within ocean floor sediments at water depths greater than about $500 \mathrm{~m}$, and at these pressures they are stable at temperatures above those for ice stability. Gas hydrates also are stable in association with permafrost in the polar regions, both offshore and onshore. In deep sea sediments, where temperature normally increases downward, a temperature eventually is reached at which hydrate is unstable, even though the pressure continues to increase with depth. The base of the hydrate stability zone will approximately parallel the sea floor at any particular water depth because the thermal gradient within a restricted area is generally fairly constant. Thus a layer within the sediments will exist in which gas hydrate is potentially stable from the sea floor down to a depth at which the gas hydrate phase boundary is reached, commonly several hundred to a thousand meters below the sea floor. If gas (methane) saturation exists within this zone, gas hydrate will form.

Gas hydrates bind immense amounts of methane in sea floor sediments. Hydrate is a gas concentrator; the breakdown of a unit volume of methane hydrate at a pressure of one atmosphere produces about 160 unit volumes of gas. The worldwide amount of methane in gas hydrates is considered to contain at least $1 \times 10^{4}$ gigatons of carbon in a very conservative estimate (Kvenvolden, 1988). This is about twice the amount of carbon that resides in all fossil fuels on earth. Furthermore, hydrates also seem to have the capacity to fill sediment pore space and reduce permeability, so that hydratecemented sediments act as seals for gas traps. Thus, there are two ways in which hydrates can create accumulations of energy gases (primarily methane, but other hydrocarbon gases, as well), both by binding gas into hydrates within sediments and by creating a trap, using hydrate-cemented sediments as the seal.

\section{PROJECT DESCRIPTION}

\section{Recognition of Gas Hydrates in Sediments by Remote Sensing Methods - Seismic Reflection Profiles}

Although hydrates have been recognized in drilled cores, their presence over large areas can be detected much more efficiently by acoustical methods, using seismic reflection profiles (Tucholke and others, 1977; Shipley and others, 1979; Dillon and Paull, 1983; Collins and Watkins, 1985; Miller and others, 1991; Rowe and Gettrust, 1993). Hydrate has a very strong effect on acoustic reflections because it has a very high acoustic velocity $(\sim 3.3 \mathrm{~km} / \mathrm{s}$ - about twice that of seafloor sediments; Sloan, 1990), and thus cementation of grains by hydrates produces a high-velocity deposit due to the mixing of hydrate with the sediment. Sediments 


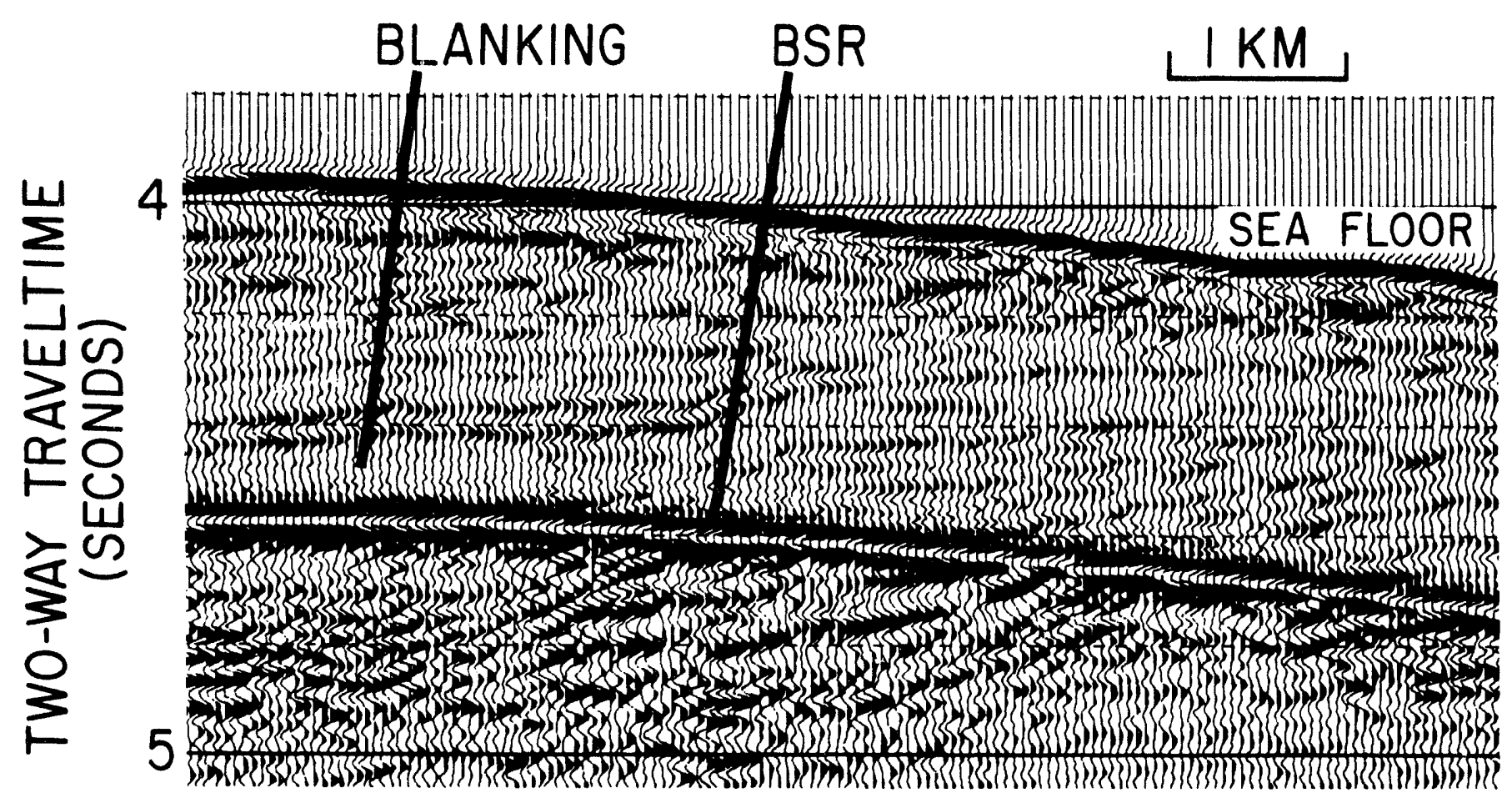

Figure 1. Seismic profile showing the reflection from the base of the gas hydrate-cemented zone (bottom simulating reflection, or BSR) and blanking of reflections in the cemented zone between the sea floor and BSR

below the hydrate zone, if water saturated, have lower velocities (water velocity is $\sim 1.5$ $\mathrm{km} / \mathrm{s}$ ), and if gas is trapped in the sediments below the hydrate, the velocity is much lower (even with just a few percent of gas; Brandt, 1960). Because reflection strength at an interface is a function of the change of acoustic impedance, which is the product of velocity times density, the base of the hydrate-cemented zone produces a very strong reflection. The reflection is also very sharply defined, because the phase boundary is a distinct, not diffuse, limit to hydrate occurrence, whereas the top of hydrate within the sediments has no such precisely defined boundary, so it does not produce a sharp reflection. As noted above, the base of hydrate stability occurs at an approximately uniform sub-bottom depth throughout a small area, and therefore the reflection from its base roughly parallels the sea floor, hence it is called the "Bottom Simulating Reflection" or BSR; the BSR is characteristic of hydrate-bearing sediments. A very strong BSR is shown in Figure 1, in which it intersects reflections from strata at locations where the stratal surfaces do not parallel the sea floor. The coincidence in depth of the BSR to the theoretical, extrapolated pressure/temperature conditions that define the hydrate phase boundary at various locations in the world and the sampling of hydrate above BSR's give confidence that this seismic indication of hydrates is dependable (Kvenvolden and Barnard, 1982, 1983; Shipley and Didyk, 1982, Kvenvolden and Kastner, 1990). 
A second significant seismic characteristic of hydrate-cementation, called "blanking" is also very well displayed in Figure 1; blanking is the reduction of the amplitude of seismic reflections caused by hydrate cementation. The amplitudes of reflections (shown by the excursions of the filled wiggle traces) are much smaller above the BSR, where sediments are cemented by gas hydrates, than they are below the BSR. This phenomenon consistently appears in sediments containing gas hydrates, indicating that the acoustic impedance changes between the strata are much reduced by hydrate cementation. A third characteristic of gas hydrates in a nearbottom layer of sediment is the abrupt velocity decrease at the level of the BSR caused by moving from hydrate-cemented sediments above the horizon to noncemented sediments below it, where sediments are water- or even gas-filled.

The BSR and velocity inversion, as seismic manifestations of hydrates in sea floor sediments, have been used to recognize gas hydrates in seismic profiles on the U.S. Atlantic continental margin (Tucholke and others, 1977; Shipley and others, 1979; Dillon and others, 1980; Paull and Dillon, 1981; Krason and Ridley, 1985). The BSR and velocity inversion are related solely to the bottom boundary of the hydrate zone. The blanking effect, however, occurs across the entire hydratecemented zone and can be quantified to estimate the amount of gas hydrate that is present (Lee and others, 1993a).

Estimating Volume of Gas Hydrate in Sediments from Seismic Reflection Data

The strong effect of gas hydrate on interval velocity would allow quantitative mapping of gas hydrate in marine sediments if the distribution of velocities in the near-bottom sediments were completely known. Interval velocity is assumed to depend on the proportions of sedimentary volume filled by rock (the sediment grains), water, and hydrate and their respective velocities. Velocity in the hydrate layer can be estimated from multichannel seismic reflection profiles or wide-angle seismic measurements, but unfortunately such data are not widely available on the east coast of the United States. The only type of digital seismic data that is available in a grid that is dense enough to allow mapping is verticalincidence seismic data. Vertical-incidence data are collected with no moveout, and therefore do not allow the calculation of interval velocities but do allow the measurement of blanking. Our strategy to estimate hydrate concentration is to quantify interval velocity and amplitude blanking due to hydrates in the few available multichannel seismic reflection profiles; estimate the amount of hydrate indicated by velocity; establish the relationship between hydrate and blanking; then apply this relationship to measure hydrate concentrations indicated by blanking in the vertical-incidence data (Lee and others, 1992; 1993a; 1993b; in press).

Initially, interval velocity and median reflectance were determined for a layer 250 milliseconds thick within the gas hydratestable layer (above the BSR) in six U.S. Geological Survey multichannel seismic profiles located in the survey area.

Blanking is measured as the decrease in median reflectance within the layer. Median reflectance is the seismic amplitude adjusted for factors other than hydrate cementation that are also known to affect amplitude; these are travel distance due to 


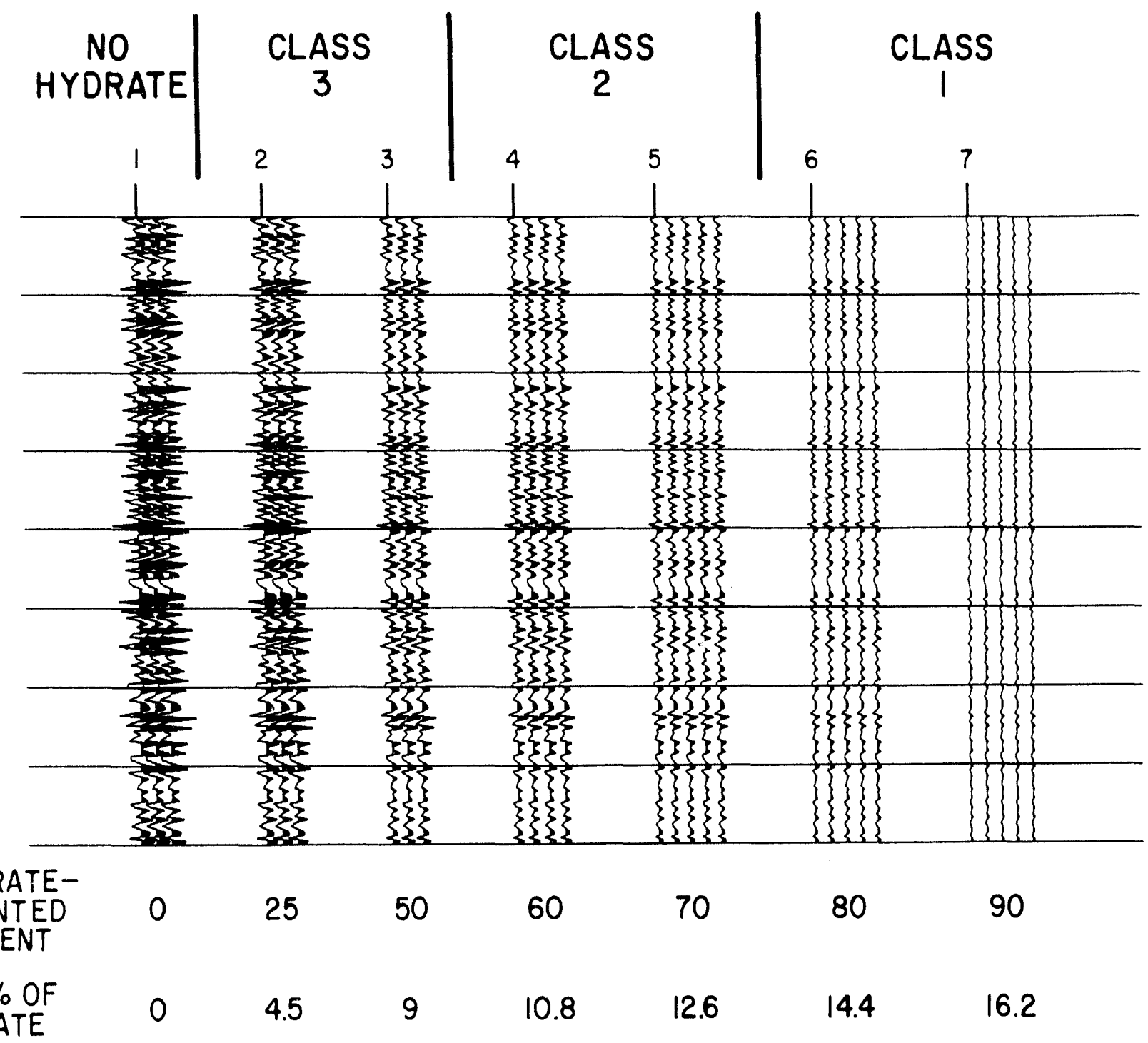

Figure 2. Synthetic seismograms showing the effect of increasing proportions of gas hydrate cement

water depth variations, and sea floor reflectivity. Concentrations of gas hydrate were calculated using the known velocities of rock, water and hydrate and the porosity, which is the proportion of sediment volume occupied by water plus hydrate. The porosity of nearbottom sediments off the southeastern United States was estimated from results of scientific drilling (Hollister, Ewing and others, 1972;

Sheridan, Gradstein and others, 1983). Once the hydrate concentrations for the six multichannel seismic lines were calculated, variations in concentration of hydrate could be correlated with the measured blanking. This relationship then was used 
to estimate the proportion of hydrate in the vertical incidence, two-channel profiles for which the calculation of velocity was not possible.

The relationship of degree of blanking to concentration of hydrate is not considered to be a precise one, so in estimating blanking in profiles, we divided the effect into just three blanking classes. Class boundaries were selected at amplitude reductions of $6 \mathrm{~dB}$. To illustrate the effect of increasing proportions of gas hydrate cement in sediments on seismic reflections and the three classes of blanking we modeled a series of synthetic seismograms (Fig. 2). In order to simulate a seismogram for non-cemented sediments, 200 random porosities in the porosity range of $50 \%$ to $70 \%$ (similar to the range in measurements for the study area) were generated and the corresponding velocities and densities were computed. We then computationally "replaced" non-hydrate-cemented sediments with increasing amounts of a representative hydrate-cemented sediment (hydrate concentration $27.5 \%$, porosity $57.5 \%$ ) and velocities and densities were modified accordingly. A reflection coefficient series was computed on the basis of the modified velocities and densities and an appropriate band-pass filter was applied. To illustrate the relationship of amplitude blanking to hydrate concentration, synthetic seismograms were plotted (Fig. 2) in which the representative hydrate-cemented sediment was replaced in non-hydratebearing sediments in proportions of $0 \%$, $25 \%, 50 \%, 60 \%, 70 \%, 80 \%$, and $90 \%$. The class boundaries also are indicated on the figure. The characteristics of the classes are shown in Table 1.

\section{DATA COLLECTION AND PROCESSING}

The majority of the seismic reflection lines used in this study were collected during five U.S. Geological Survey cruises from February to May, 1987, of the R/V Farnella, which were intended primarily to collect GLORIA sidescan sonar data. A 160 in $^{3}$ airgun was fired at 10 second intervals, and data were recorded digitally at sea using a 2-channel hydrophone streamer. Sidescan sonar mosaics and unprocessed seismic reflection, bathymetric and magnetic profiles collected on these cruises are presented in EEZ-Scan 87, Scientific Staff (1991). Additional seismic reflection lines were run on the R/V Cape Hatteras in 1991. These lines were collected using a 120 in $^{3}$ airgun fired at 10 second intervals and also recorded digitally at sea from a 2-channel hydrophone streamer.

To enhance the appearance of the sub-

Table 1. Properties of the hydrate classes

$\begin{array}{llll} & \text { Class I } & \text { Class II } & \text { Class III } \\ \text { median reflectance } & <0.024 & 0.05-0.025 & >0.05 \\ \text { bulk volume of hydrate } & 12 \%-16 \% & 8 \%-12 \% & 0 \%-8 \% \\ \text { average volume of hydrate } & 14 \% & 10 \% & 4 \% \\ \text { range in interval velocity }(\mathrm{km} / \mathrm{s}) & 1.94-2.02 & 1.85-1.94 & 1.7-1.85\end{array}$




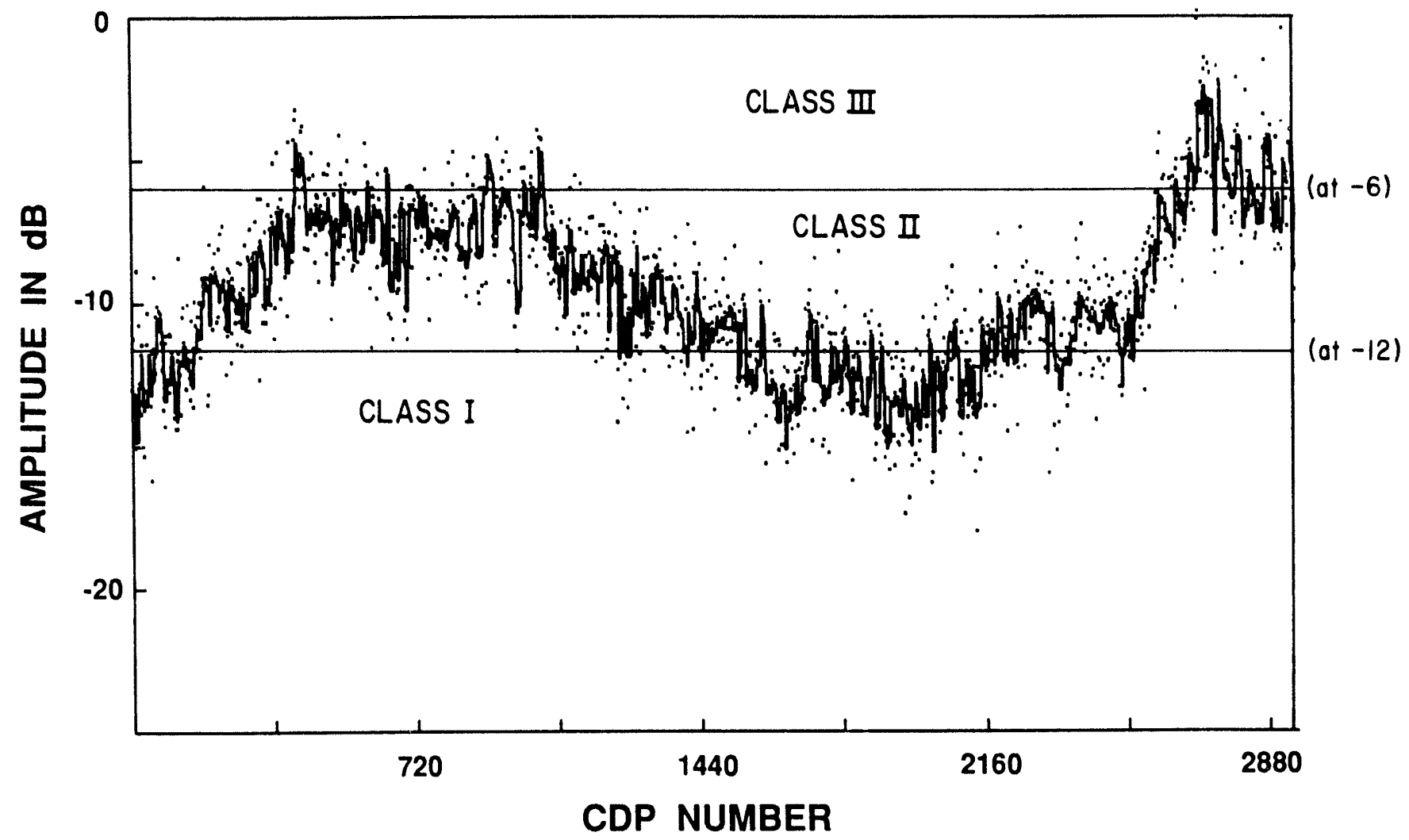

Figure 3. Plot of median reflectance in a window 250 to 500 milliseconds below the sea floor along a seismic profile. Dots indicate individual values, line represents a 5-point moving median of values shown by dots.

bottom region where blanking and the BSR are present, the following processes and process parameters were used: debias, mute, gain proportional to first power of travel time, deconvolution (design window $=0-1.4$ seconds below the seafloor; filter length $=.16$ seconds; prewhitening $=10 \%$; prediction distance $=.02$ seconds), bandpass filter (passed between 10-100 Hz), and 2channel stack. The stack summed the two channels with no moveout correction applied, and served to increase the signalto-noise ratio compared to single channel display. This processing strategy preserved relative true amplitudes. From these processed data, median reflectance was estimated for a window extending from 250 to 500 milliseconds below the sea floor (within the gas-hydrate stable zone) and a plot was created of median reflectance along the profile with a moving average applied (Fig. 3).

\section{Mapping}

Median reflectance plots along each seismic section allowed assignment of average class level (I, II or III) within the selected 250-500 millisecond window (Fig. 3 ). Using this calibration as a guide, an 


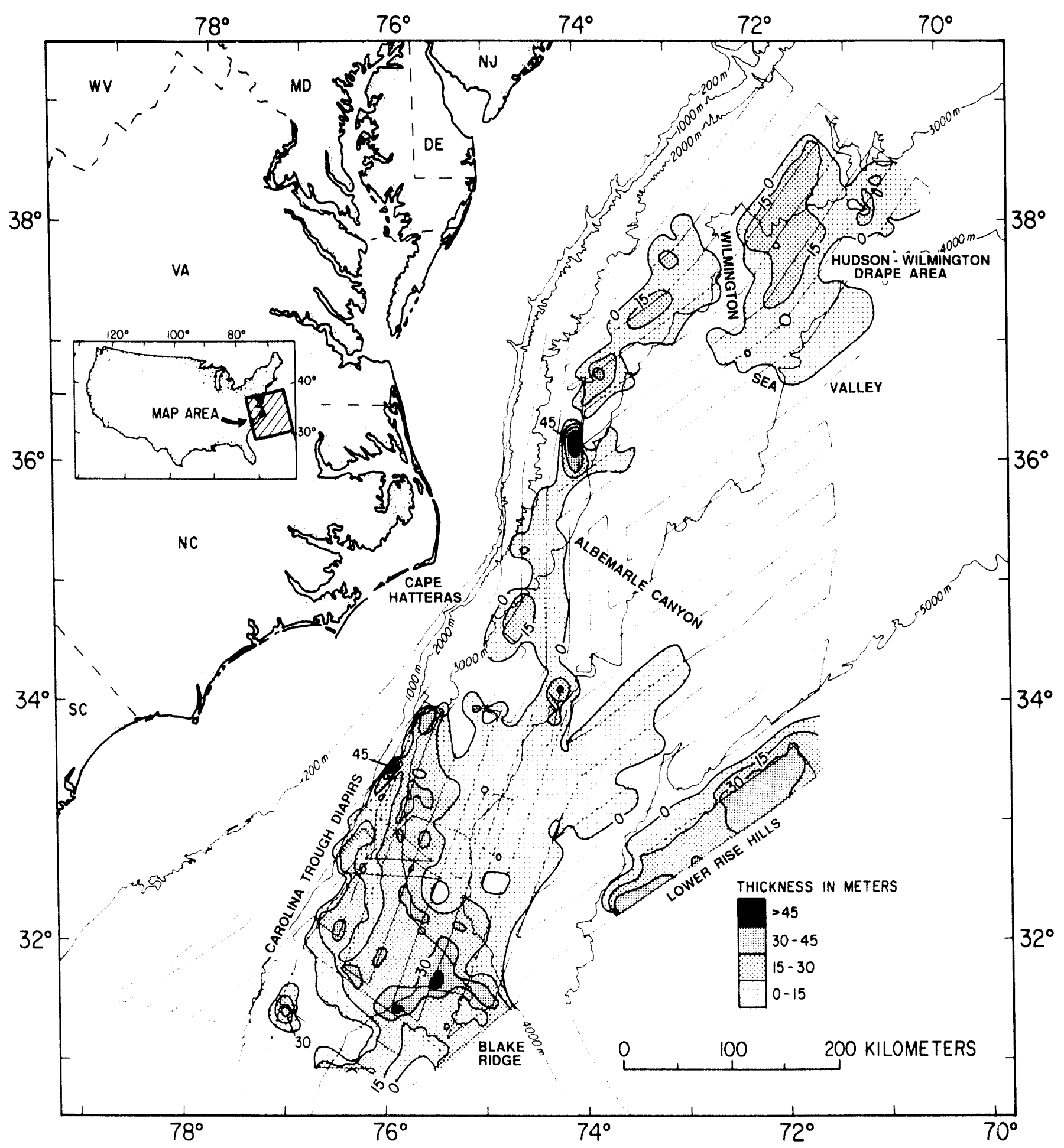

Figure 4. Volume of gas hydrate shown by isopach contours for the eastern continental margin of the United States - contour interval $=15$ meters 


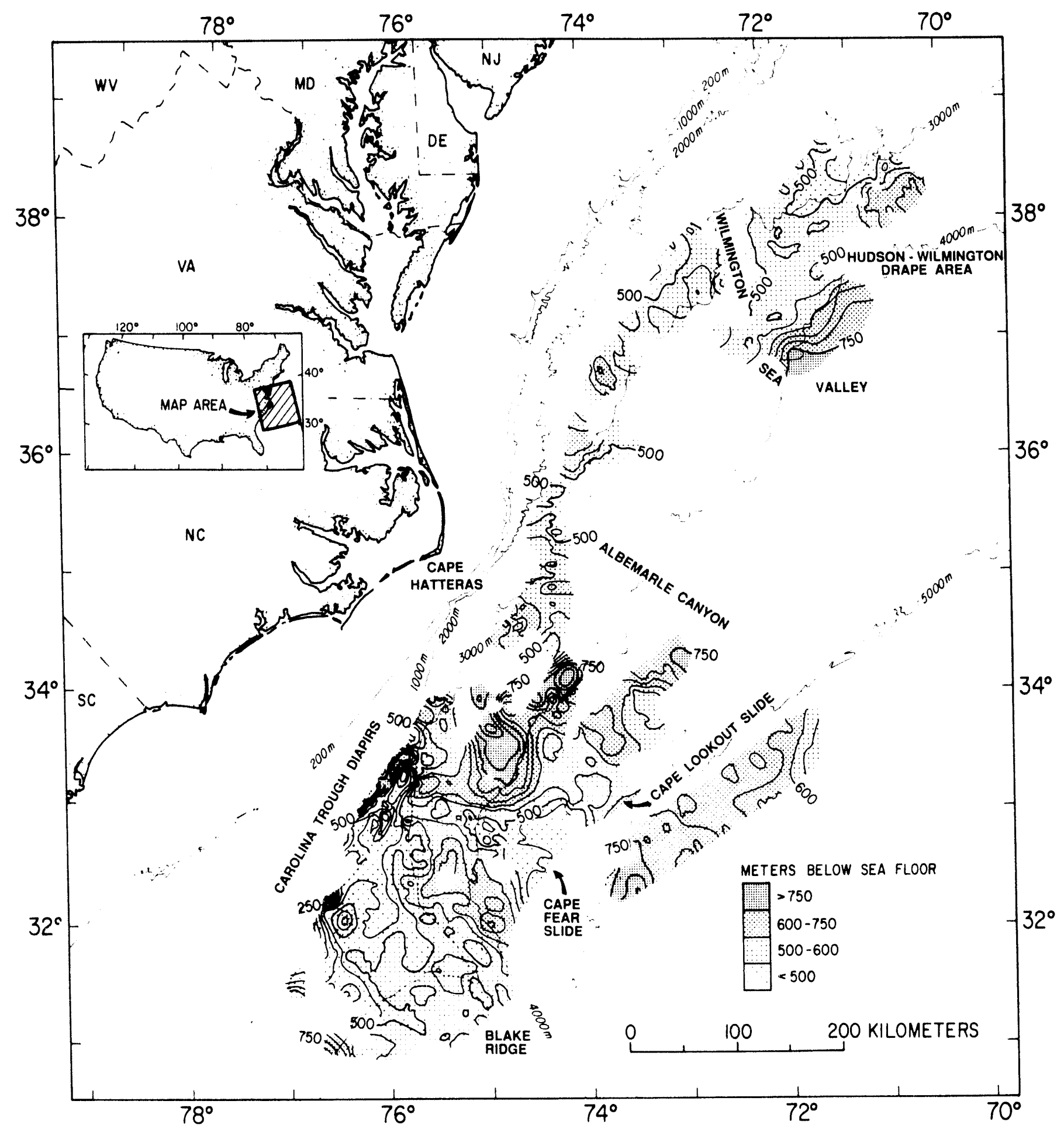

Figure 5. Thickness of the gas hydrate layer (sea floor to BSR) for the eastern continental margin of the United States - contour interval $=50$ meters 
interpretation of the areal extent of each class was drawn on each seismic section. Then each of these interpretations was digitized, the values of thickness in acoustic travel time for each class were multiplied by appropriate velocities for that class (Table 1 ), and a summary of the volume distribution of deposits representing each class was made by integrating between the profiles using a surface-modeling, gridding, and contouring program.

To map total hydrate, the volume of each class was multiplied by the average proportion of gas hydrate for that class and the results for the three classes were summed. This resulted in the estimate of total volume of gas hydrate for the study area that is shown by the isopach contours of Figure 4. The quantity of hydrate is expressed by contours showing inferred volume of hydrate existing within the sediments; that is, the amount of hydrate that would appear if all the hydrate dispersed in the sediments were extracted and piled on the sea floor above.

Figure 5 is a map of the depth of the BSR below the sea floor; this interval from sea floor to BSR - represents the zone in which gas hydrate is stable. This map also was created using the seismic data and the interpretation of classes. The depth of the BSR at a point was calculated by identifying the thickness in acoustic travel time for deposits of each class and multiplying the time-thickness of each class by a characteristic velocity associated with that class (Table 1). These thicknesses were then summed to get the total depth to the base of gas hydrate. Velocities used were: Class I, $2 \mathrm{~km} / \mathrm{s}$, Class II, $1.9 \mathrm{~km} / \mathrm{s}$, Class III, $1.8 \mathrm{~km} / \mathrm{s}$.

\section{RESULTS}

These maps (Figs. 4 and 5) represent the first attempt to map volume estimates for gas hydrate. They present the inferred volume distribution (Fig. 4) of natural gas hydrate and the thickness of the hydratestable layer (Fig. 5) within the sediments of the eastern United States continental margin (Exclusive Economic Zone) in the offshore region from Georgia to New Jersey.

\section{Gas Hydrate Distribution}

Most concentrations of gas hydrate represent locations where sedimentation rates either are high or have been high in the geologically recent past, because these are areas where organic material is preserved and converted to biogenic gas by bacteria in the sediments (Dillon and others, 1993; in press). Regions of active high deposition and hydrate concentration include the Hudson Wilmington drape area and the Lower Rise Hills (Fig. 4). On the other hand, the Blake Ridge hydrate deposit (Fig. 4), which is the the greatest concentration of hydrate off the eastern United States, is located at a site of active Miocene/Pliocene deposition. Other concentrations of gas hydrate are located at sites of diapirs and associated faults (Carolina Trough Diapirs, Fig. 4; Schmuck and Paull, 1993). Note the very strong blanking around the diapir (Fig. 6). Gas near diapirs may have a thermogenic source, perhaps having migrated up faults from deep sources (Fig. 7).

\section{Gas Hydrate Layer Structure}

Because gas hydrate is stable to higher temperatures as pressure increases and because pressure increases as water becomes 


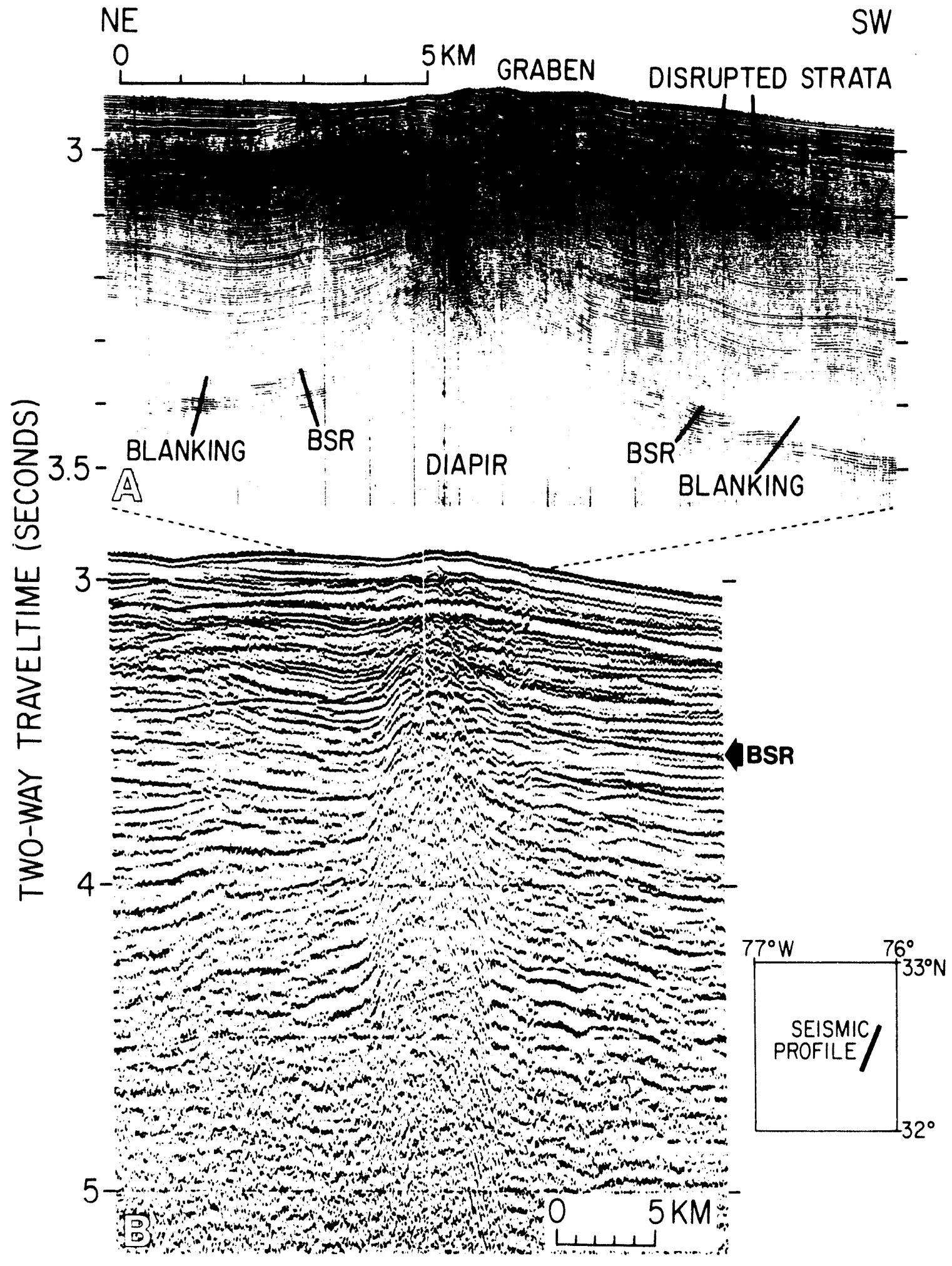

Figure 6. Seismic profile across a diapir on the South Carolina continental rise $-\mathbf{A}$, high resolution profile (seismic source $=5$ cubic inch airgun) $-B$, deep penetration profile (seismic source $=$ two 500 cubic inch airguns) 
SEA FLOOR

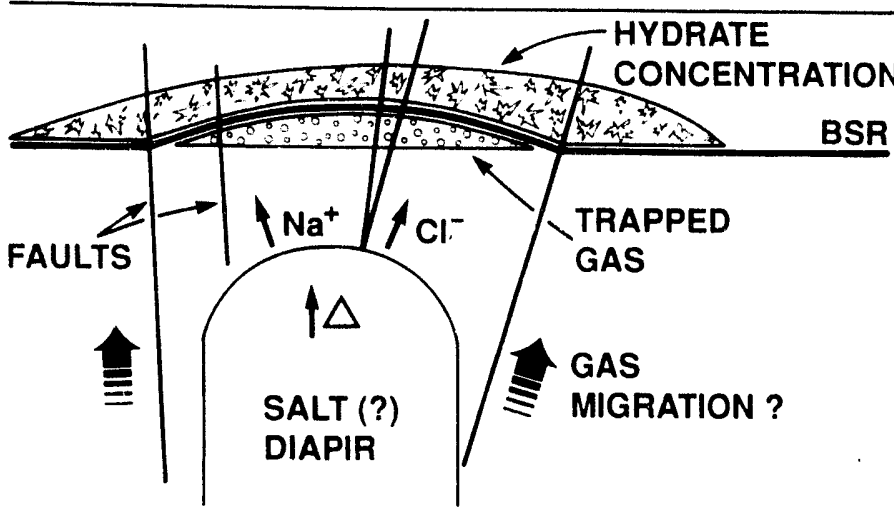

Figure 7. Conceptual sketch of the effects of a salt diapir on an overlying gas hydrate layer

deeper, the base of hydrate stability might be expected to extend progressively deeper into the sediments as water depth increases, assuming that pressure change depends only on change of water depth and that the thermal and chemical regimes are constant. Clearly, the structure of the gas hydrate layer (Fig. 5) is far more complicated than anticipated and thus is alfected by factors other than just pressure due to water depth (Dillon and others, 1993; in press). Hydrate thins above diapirs (Carolina Trough Diapirs, Fig. 5), where the greater thermal conductivity of salt creates a warm spot and salt ions act as antifreeze, both effects resulting in a local shallowing of the base of the hydrate (Figs. 6 and 7; Schmuck and Paull, 1993). The thickness of the gas hydrate layer also decreases markedly at landslide scars (e.g. Cape Fear Slide, Fig. 5). The relationship might result because the slides may have been initiated by a breakdown of hydrate that was caused by glacial lowering of sea level and the accompanying pressure reduction at the sea floor. The slide itself then might cause a secondary pressure reduction by removing hydrate-cemented sediments and, in turn, initiate subsequent cascading slides (Fig. 8).

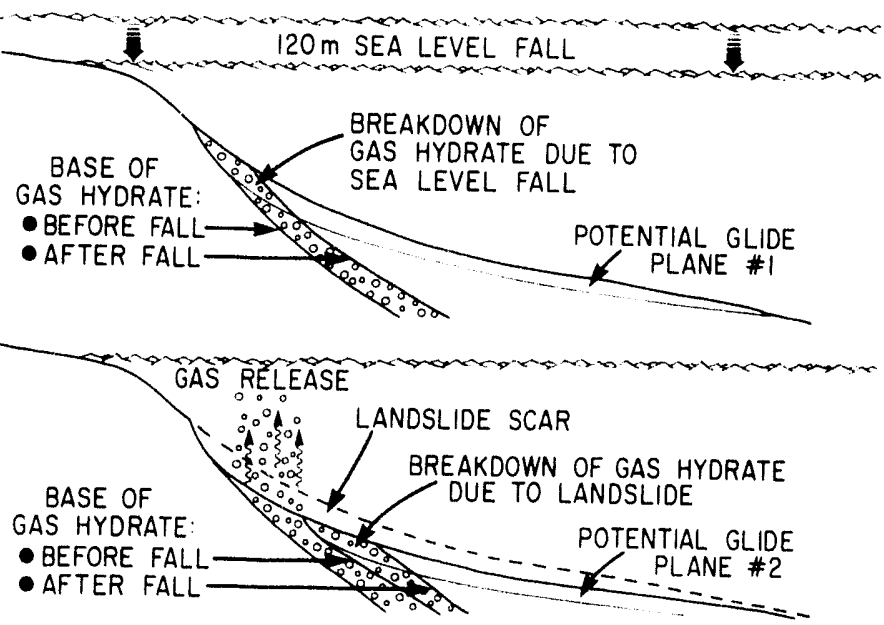

Figure 8. Conceptual sketch indicating pressure reduction effects of both sea level fall and removal of sediments by landsliding. These cause breakdown of hydrate and facilitate possibly cascading landslides.

\section{Gas Traps Formed by the Hydrate Layer}

Profiles show that the hydratecemented layer can form an impermeable seal and thus that hydrate-cemented sediments can create gas traps if configured properly. The simplest gas trap of this sort occurs when the sea floor, and therefore the hydrate layer forms a dome shape as occurs at the Blake Ridge (Fig. 4). A profile of the ridge is shown in Figure 9, in which the region marked by the strong BSR probably represents a region of trapped gas.

Strata that dip relative to the sea floor commonly are intersected at their updip ends by the gas hydrate layer. When these consist of alternating porous/permeable 


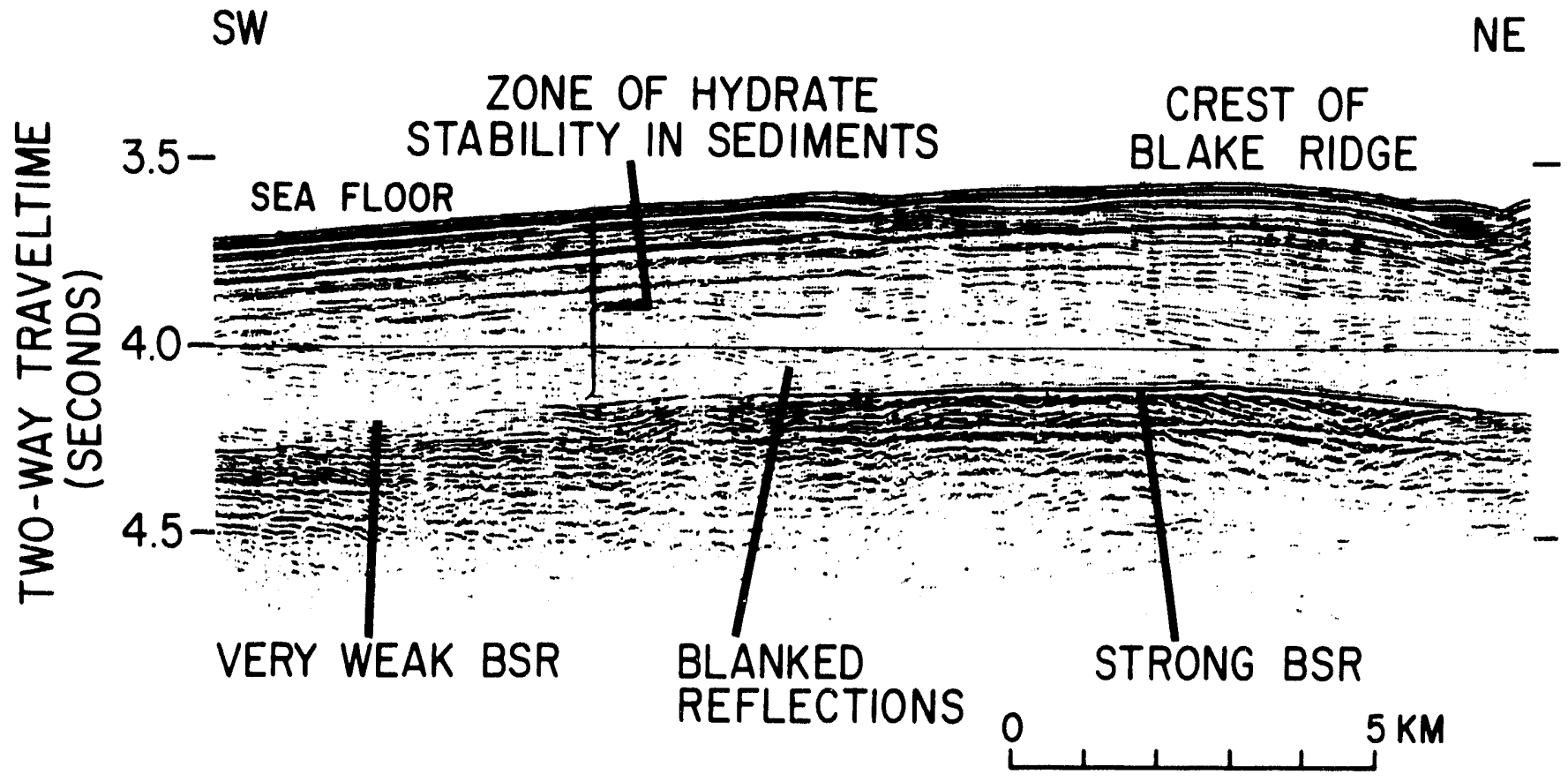

Figure 9. Seismic profile across the crest of the Blake Ridge off South Carolina. The crest of the ridge probably traps gas beneath the area of strong BSR.

and impermeable beds, the permeable layer can be sealed at its updip end by the gas hydrate cemented layer, forming a trap (Fig.10). The strongly-reflecting horizons that occur beneath the strong BSR probably represent strata containing free gas in Figure 10.

A dome can be formed in the gas hydrate seal above diapirs just by thinning of the gas hydrate stable layer by thermal and geochemical factors as discussed above (Figs. 6 and 7). Gas-charged layers sealed beneath such a dome appear in Figure 6A as a series of strong reflections that terminate against the blanked zone that contains hydrate. Gas traps formed by domes in the base of hydrate above salt diapirs commonly are small and perhaps are more significant as a drilling hazard than as a resource.

\section{FUTURE WORK}

Future work includes further seismic studies and laboratory analysis of simulated and natural marine gas hydrates. We collected $1367 \mathrm{~km}$ of new seismic data in 1992, mostly in a dense grid on the Blake Ridge, the region of highest hydrate concentration observed in our previous mapping. Processing of these data is underway. A laboratory system has been completed that will allow the formation of gas hydrate-cemented sediments at temperatures and pressures simulating ocean depths to $2400 \mathrm{~m}$. (Figs. 11 and 12). Testing will include measurements of 


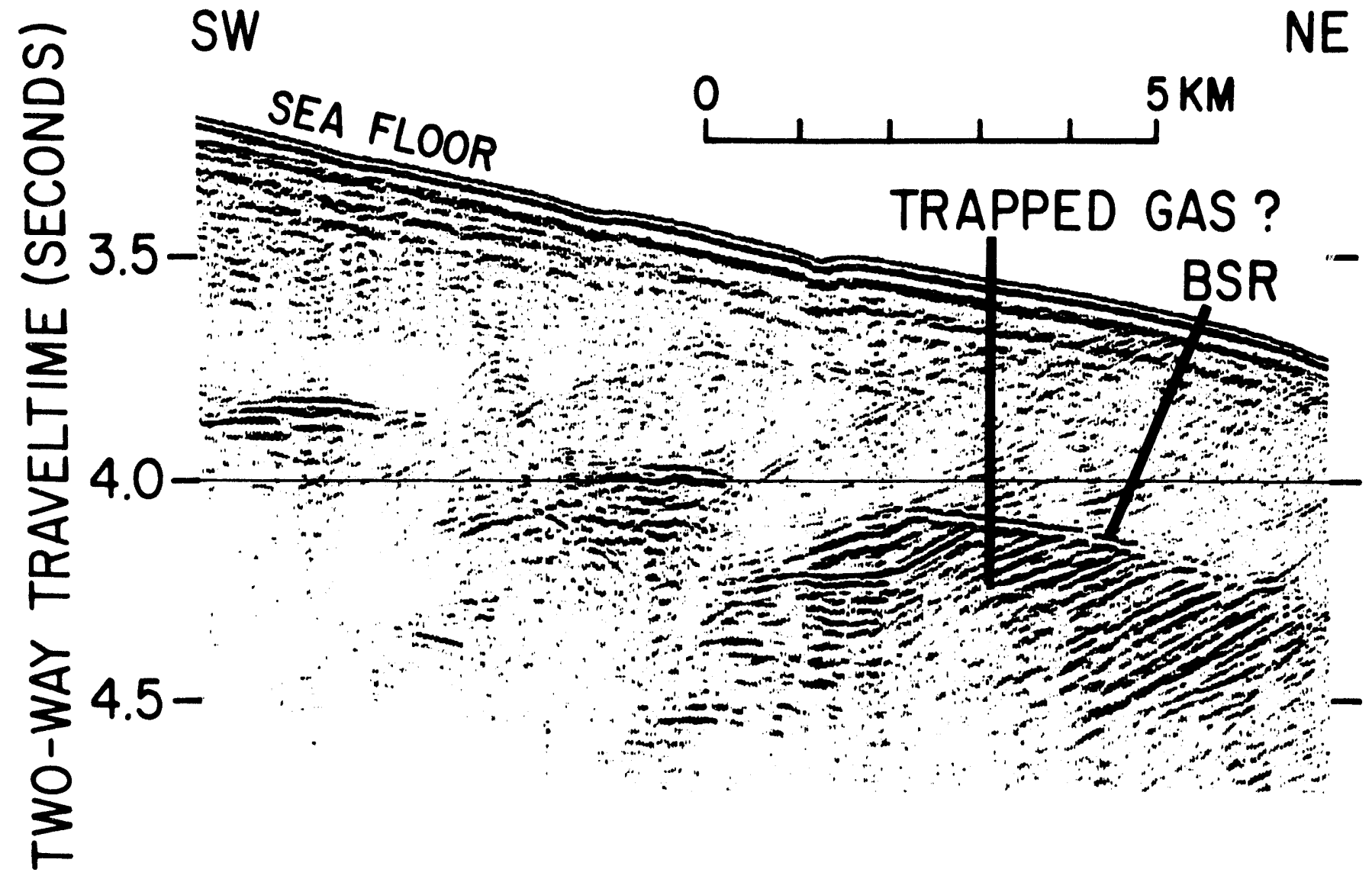

Figure 10. Dipping strata sealed at their updip end by the gas hydrate-cemented sedimentary layer and probably containing trapped gas

acoustic velocity, electrical resistivity, and physical properties. We also are involved in planning drillsites in the Blake Ridge region that have been proposed to the Ocean Drilling Project. Natural samples from areas that have been studied by seismic methods will provide ground truth and immensely increase our knowledge of hydrate distribution in nature.

\section{References}

Brandt, H., 1960, Factors affecting compressional wave velocity in unconsolidated marine sand sediments, Journal of the Acoustical Society of America, v. 32, p. 171-179.

Collins, B. P. and Watkins, J. S., 1985, Analysis of a gas hydrate off southwest Mexico using seismic processing techniques and Deep Sea Drilling Project Leg 66 results, Geophysics, v. 50, p. 813-828.

Dillon, W. P., Lee, M. Y., and Coleman, D. $F$., in press, Identification of marine 


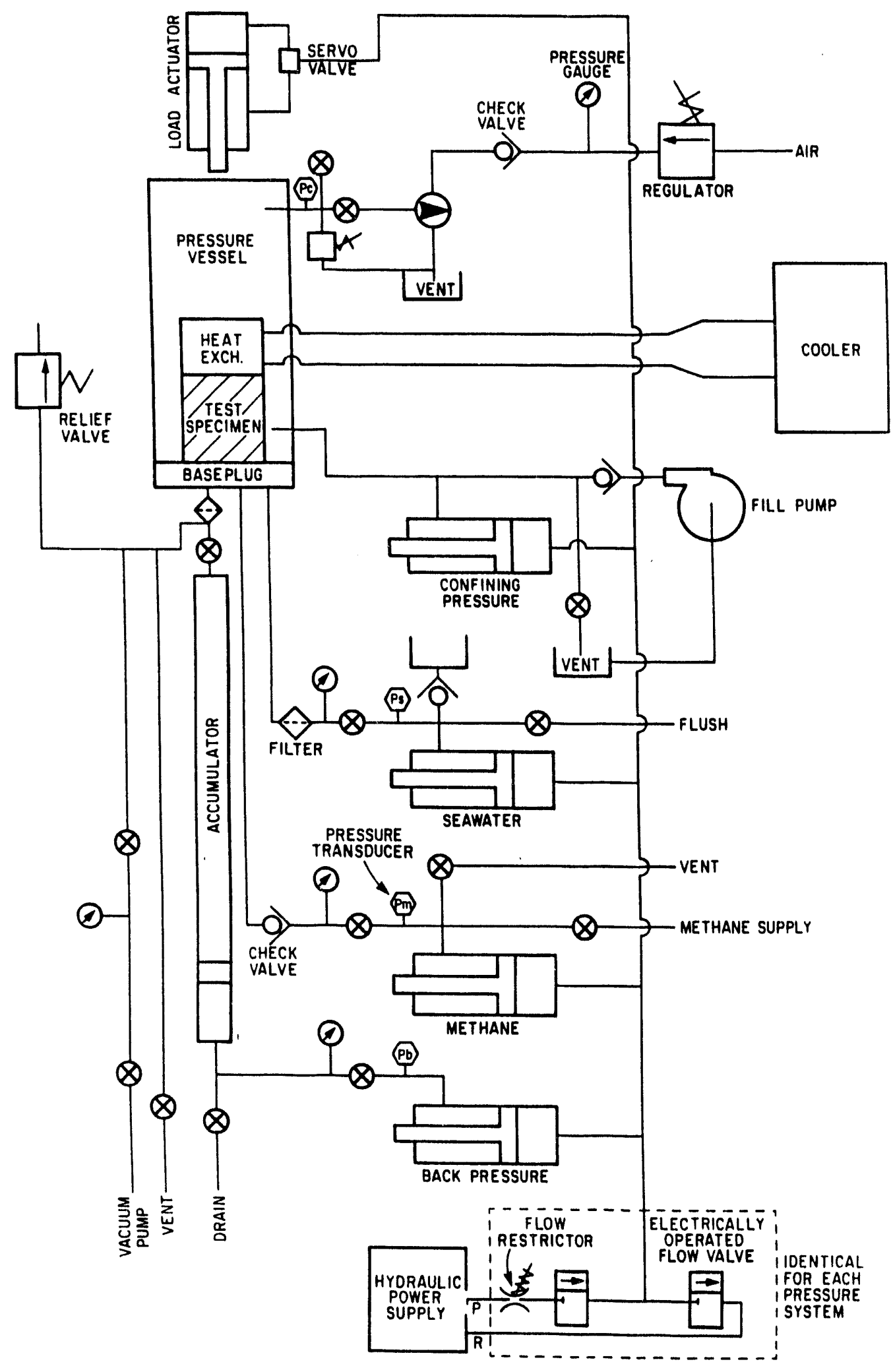

Figure 11. Diagram of the U.S. Geological Survey test system for analyzing gas hydratecemented sediments at sea floor conditions 


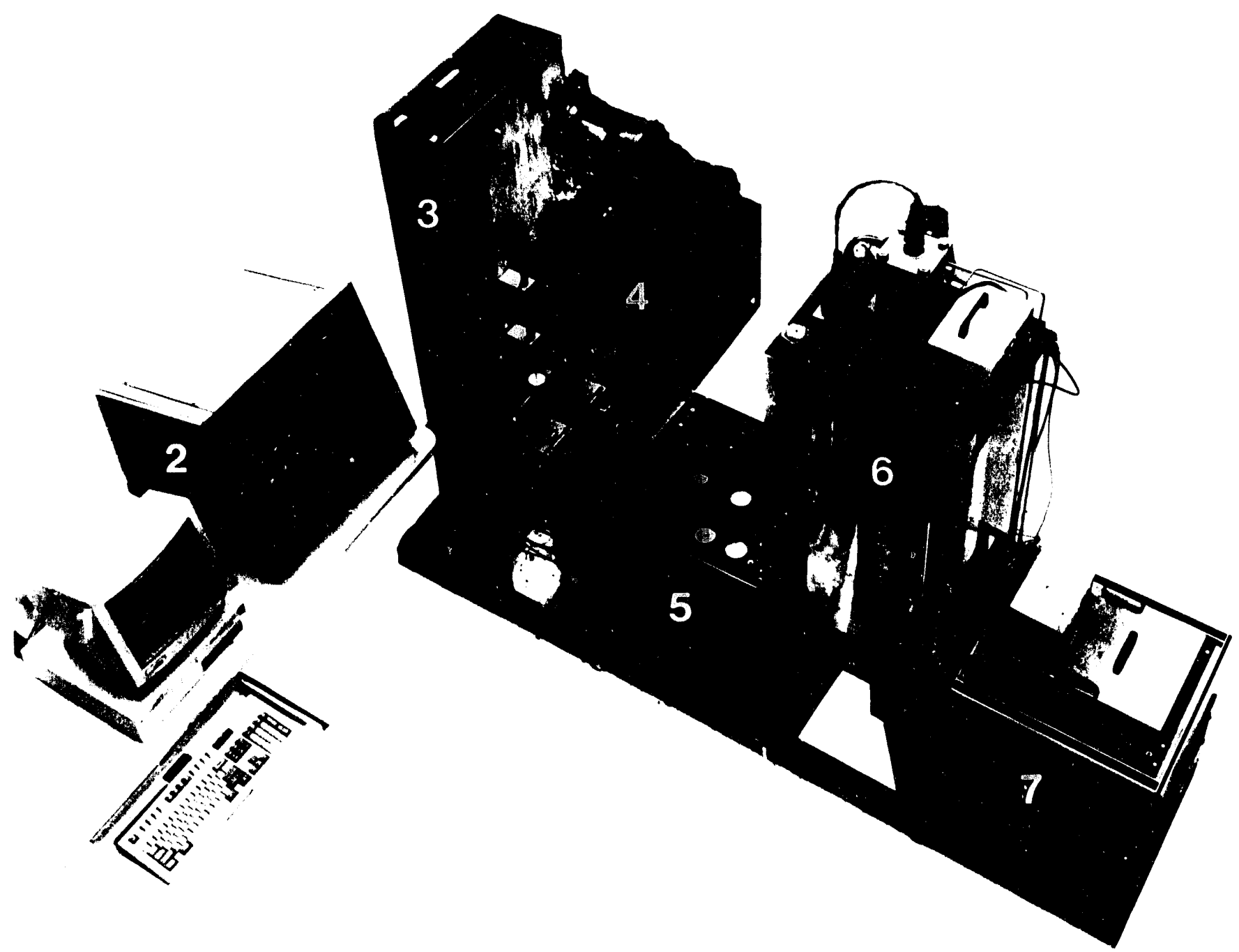

Figure 12. Photograph of the gas hydrate test system diagramed in Figure 11. 1. computer, 2. servo-controller and pressure control panel, 3. confining pressure, back pressure, seawater, and methane intensifier panel, 4. hydraulic power supply, 5. main valve control panel, 6. specimen chamber and load frame, 7. refrigeration system and pressure vessel valve control panel

hydrates in situ and their distribution off the Atlantic coast of the United States, International Conference on Natural Gas Hydrates, Annals of the New York Academy of Sciences.
Dillon, W. P., Grow, J. A., and Paull, C. K., 1980, Unconventional gas-hydrate seals may trap gas off southeast U.S., Oil and Gas Journal, v. 78, no. 1, p.124,126, 129, 130. 
Dillon, W. P., Lee, M. W., Fehlhaber, Kristen and Coleman D.F., 1993, Gas hydrates on the Atlantic margin of the United States - controls on concentration, (in) Howell, D. G., ed., U.S. Geological Survey, Prof. Pap. 1570, p. 313-330.

Dillon, W. P., and Paull, C. K., 1983, Marine gas hydrates - II: Geophysical Evidence, in Cox, J. L., ed., Natural Gas Hydrates: Properties, Occurrences and Recovery, Butterworth Publishers, Boston, p. 73-90.

Collins, B. P. and Watkins, J. S., 1985, Analysis of a gas hydrate off southwest Mexico using seismic processing techniques and Deep Sea Drilling Project Leg 66 results, Geophysics, v. 50, p. 813-828.

EEZ-Scan 87, 1991, Atlas of the U.S. Exclusive Economic Zone, Atlantic continental margin, U. S. Geological Survey, Miscellaneous Investigations Series I-2054, $174 \mathrm{p}$.

Hollister, C. D., Ewing, J. I., and others, 1972, Initial reports of the Deep Sea Drilling Project, vol. 11, Washington (U.S. Government Printing Office).

Krason, J. and Ridley, W. I., 1985, Geological evolution and analysis of confirmed or suspected gas hydrate localities, Vol. 1. Blake-Bahama Outer Ridge U.S. East Coast, DOE/MC/21181 (DE86001006), $100 \mathrm{p}$.

Kvenvolden, K. A., 1988, Methane hydrate A major reservoir of carbon in the shallow geosphere?, Chemical Geology, v. 71, p. 41-51.
Kvenvolden, K. A., and Barnard, L. A., 1982, Hydrates of natural gas in continental margins, in Watkins, J. S. and Drake, C. L., eds., Studies of Continental Margin Geology, Memoir No. 34, American Association of Petroleum Geologists, p. 631-640.

Kvenvolden K. A. and Barnard, 1983, Gas hydrates of the Blake Outer Ridge, Site 533, Deep Sea Drilling Project Leg 76, in Sheridan, R. E. and Gradstein F., and others, Initial Reports of the Deep Sea Drilling Project, vol. 76, U.S. Government Printing Office, Washington, D.C., p. 353-365.

Kvenvolden, K. A., and and Kastner, M. 1990, Gas hydrates of the Peruvian outer continental margin, in Suess, E. R., von Huene, R., and others, Proceedings of the Ocean Drilling Program, Scientific Results, v. 112, p. 517-526.

Lee, M. W., W. P. Dillon, and D. R. Hutchinson, 1992, Estimating the amount of gas hydrate in marine sediments in the Blake Ridge area, southeastern Atlantic Margin, U. S. Geological Survey, Open-File Report, 92-275, $24 \mathrm{pp}$.

Lee, M. W., Hutchinson, D. R., Agena W. F., Dillon, W. P., Miller, J. J., and Swift, B. A., in press, Seismic character of gas hydrates on the southeastern U.S. continental margin, 32 pp., 14 figs., Marine Geophysical Researches.

Lee, M. W., Hutchinson, D. R., Dillon, W. 
P., Miller, J.J., Agena, W. F. and Swift, B. A., 1993a, Method of estimating the amount of in situ gas hydrates in deep marine sediments, Marine and Petroleum Geology, vol. 10, p. 493506.

Lee, M. W., Hutchinson, D. R., Dillon, W. P., Miller, J.J., Agena, W. F. and Swift, B. A., 1993b, Use of seismic data in estimating the amount of in -situ gas hydrates in deep marine sediment, (in) Howell, D. G., ed., U.S. Geological Survey, Prof. Pap. 1570, p. 563-582.

Miller, J. J., Lee, M. W., and von Huene, Roland, 1991, An analysis of a seismic reflection from the base of a gas hydrate zone, offshore Peru, American Association of Petroleum Geologists Bulletin, v. 75, p. 910-924.

Paull, C. K., and Dillon, W.P., 1981, Appearance and distribution of the gas hydrate reflection in the Blake Ridge region, offshore southeastern United states, U.S. Geological Survey Miscellaneous Field Studies Map MF1252.

Rowe, M. M., and Gettrust, J. F., 1993, Fine structure of methane bearing sediments on the Blake Outer Ridge as determined from deep-tow multichannel seismic data, Journal of Geophysical Research, v. 98, p. 463473.

Schmuck, E. A., and Paull, C. K., 1993, Evidence for gas accumulation associated with diapirism and gas hydrates at the head of the Cape Fear slide, Geo-Marine Letters, vol. 13, p. 145-152.
Sheridan, R. E., and Gradstein, F. M., and others, 1983, Initial reports of the Deep Sea Drilling Project, vol. 76, Washington (U.S. Government Printing Office).

Shipley, T. H. and Didyk, B. M., 1982, Occurrence of methane hydrates offshore southern Mexico, in Watkins, J., S., Moore, J. C., and others, Initial Reports of the Deep Sea Drilling Project, vol. 66, U.S. Government Printing Office, Washington, D.C., p. 547-555.

Shipley, T. H., Houston, M. H., Buffler, R. T., Shaub, F. J.,McMillen, K. J., Ladd, J. W., and Worzel, J. L, 1979, Seismic evidence for widespread possible gas hydrate horizons on continental slopes and rises, American Association of Petroleum Geologists Bulletin, v. 63, p. 2204-2213.

Sloan, E. D., Jr., 1990, Clathrate hydrates of natural gases, Marcel Dekker, Inc., New York, $641 \mathrm{p}$.

Tucholke, B. E., Bryan, G. M., and Ewing, J. I.,1977, Gas-hydrate horizons detected in seismic profile data from the western North Atlantic, American Association of Petroleum Geologists Bulletin, v. 61, p.698-707. 

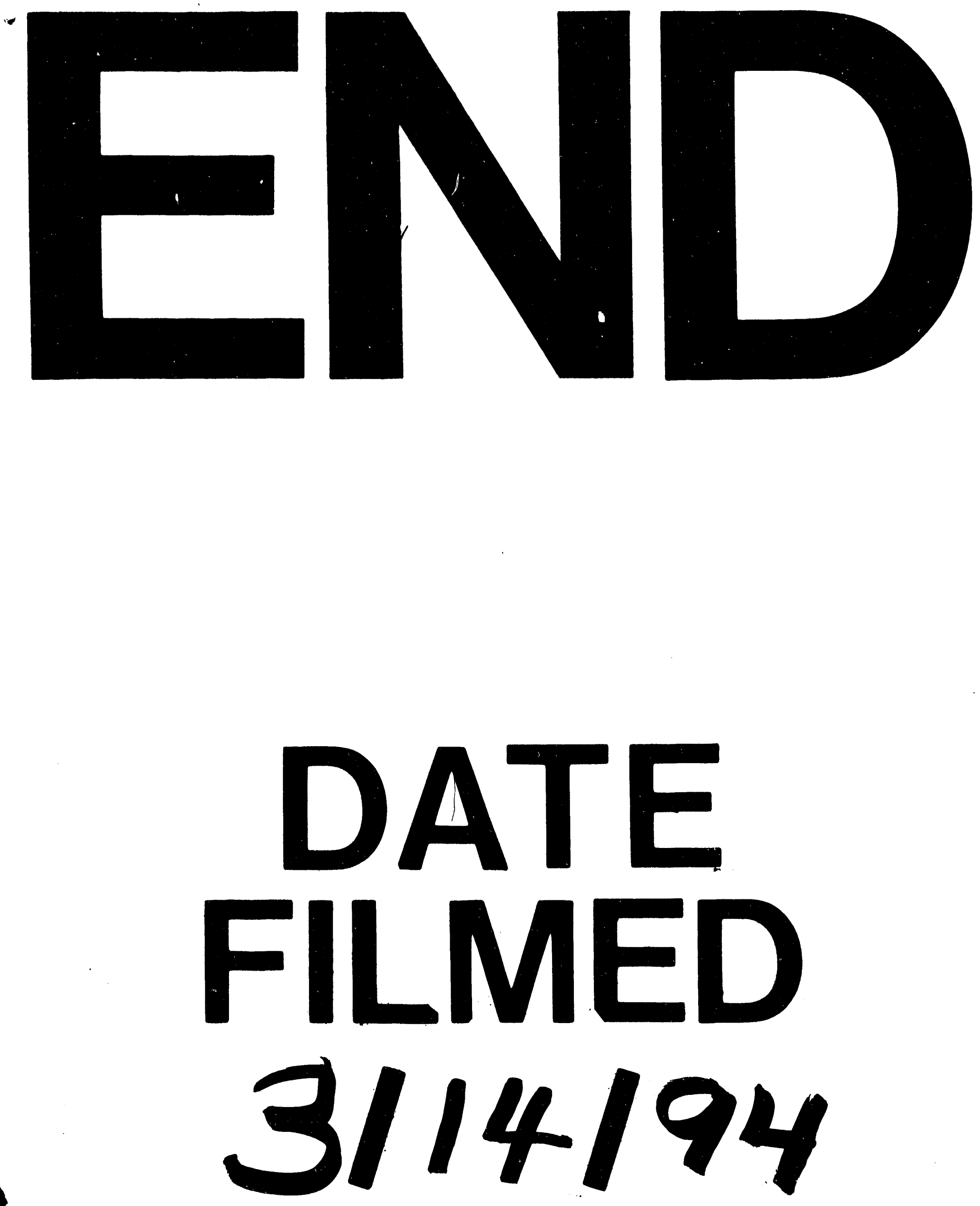
